unduly into unsettled questions. It would seem, for example, that a modern treatise on the subject ought to make some use of the masterly contributions of BRown and Escombe on the energy and material exchanges of the green leaf, and of FitTing's telling work on geotropism.

The order of treatment differs from that of most English and German works. The headings of the chapters are as follows: (I) nutritive reserves; (2) respiration; (3) fermentation; (4) assimilation of carbon; (5) mineral nutrition; (6) circulation of water; (7) transpiration; (8) latent life and development; (9) movements; (Io) influences of environment; (II) physiology of the species.

The agricultural significance of the subject is emphasized. In the main this is done by using data gained from a study of the economic plants. The book is not indexed, but this is partly cared for by a full table of contents.WiLliam CROCKER.

\title{
MINOR NOTICES
}

Das Pflanzenreich.4-Part 43 contains the first portion of a monographic treatment of the Umbelliferae by Dr. Hermann Wolff. The present part includes 9 genera of the tribes Apioideae and the heteroclitus Ammineae, to which are referred about 150 species. The body of the publication is occupied mainly with the genus Bupleurum, which is represented by approximately Ioo species, nearly all occurring in the northern hemisphere. One new genus (Ledebouriella) is proposed, being based on Rumia multiflora Ledeb. of uncertain native habitat and $R$. seseloides Hoff. from the Altai.

Part 44 continues the elaboration of the Euphorbiaceae by Professor F. PAX and concerns only the tribe Adrianeae. The author recognizes 8 genera and 144 species, of which 34 are new to science. One new genus (Cephalocrotonopsis) is described, founded on Cephalocroton socotranus Balf. f. from the steppes of northern Africa. Of the 8 genera constituting the tribe, the genus Manihot comprises by far the largest number of species (1 29), and these have their center of distribution in Brazil.

Part 45 is devoted to a monographic consideration of the tribe Dendrobiinae of the Orchidaceae by the noted specialist Professor FR. KRÄNZLIN. Seven genera are elaborated, the first in importance being Dendrobium. This genus, as here treated, includes approximately 600 species, numerous varieties, and over 80 hybrids; and its greatest specific diversity is in the Monsoon region of the Old World. The genus is divided into ten subgenera which are

${ }^{4}$ Engler, A., Das Pflanzenreich. Heft 43 (IV. 228). Umbelliferae-ApioideaeBupleurum, Trinia et reliquae Ammineae heteroclitae von Hermann Wolfr. pp. 214. figs. 24 (I55). M I0.80. Heft 44 (IV. I47. II). Euphorbiaceae-Adrianeae von F. PAX. pp. III. figs. 35 (I5I). M 5.70. Heft 45 (IV. 50. II. B. 2I). OrchidaceaeMonandrae-Dendrobiinae von Fr. KRÄnzlin. pp. 382. figs. 35 (327). M I9.20. Leipzig: Wilhelm Engelmann. rgro. 
based on the general character of the stems, leaves, and inflorescence. About 50 of the species recorded are new to science. The excellent keys, full descriptions, and numerous habital and detailed illustrations render this an exceedingly important treatise on a most difficult but highly interesting group of plants.-J. M. Greenman.

The Australian pines.-An elaborate volume records the results of the labors of BAKER and SMITH ${ }^{5}$ in studying the "pines of Australia." Curiously enough, there are no pines in Australia, the Abietineae being the only one of the six tribes of conifers unrepresented. The feature of the book is the wealth of illustrations, almost all of which are reproductions of photographs, many of which were made by the natural color process. The technical skill-shown in this photographic work is to be highly commended, and probably in no other publication have conifers such a setting. The motive of the work is confessedly economic, and this aspect of the Australian conifers is doubtless presented with a completeness that leaves little to be desired. It seems that Callitris, next to Eucalyptus, is the most important genus of Australian trees; and the authors have indicated its complete generic separation from Widdringtonia of South Africa and Tetraclinis of North Africa, which makes it a genus restricted to Australia and Tasmania. In presenting the eleven genera of the region, the authors include so many details of structure and of products that the volume is a thesaurus of observations for those who are in a position to estimate their value. In the presentation of each species, after an account of its history and its taxonomic characters, there are described fully the economics, anatomy, and chemistry of leaves, fruits, timber, and bark.-J. M. C.

Conservation.-Because of the loose talk current concerning the conservation of our resources, it is well to have an authoritative treatise on the subject by one of acknowledged competence. Such a treatise is the one from the hand of President VAN HISE of the University of Wisconsin, ${ }^{6}$ which is based on lectures before students. Botanists will be interested especially in the chapter on forests, and in the one on land, in which soil conservation is considered. The author's expert training as a geologist fits him peculiarly for his consideration of the mineral resources, and scarcely less so for his treatment of the soils. The final chapter deals with conservation and mankind, and there are three appendices, which give declarations of conservation principles as set forth by various organizations.-H. C. CowLEs.

${ }^{5}$ Baker, Richard T., and Smith Henry, G., A research on the pines of Australia. Technological Museum, New South Wales. 4to. pp. xiv +458. figs. 300. maps 3. Sydney: Government Printer. I9ro.

${ }^{6}$ VAN Hise, C. R., The conservation of natural resources in the United States. 8vo. pp. xiv+413. pls. I6. New York: The Macmillan Co. I9ro. \$2.00. 


\section{$2 \mathrm{BHL}$ Biodiversity Heritage Library}

Greenman, J. M. 1911. "Das Pflanzenreich." Botanical gazette 51(5), 394-395. https://doi.org/10.1086/330533.

View This Item Online: https://www.biodiversitylibrary.org/item/109457

DOI: https://doi.org/10.1086/330533

Permalink: https://www.biodiversitylibrary.org/partpdf/223438

\section{Holding Institution}

Missouri Botanical Garden, Peter H. Raven Library

\section{Sponsored by}

Missouri Botanical Garden

\section{Copyright \& Reuse}

Copyright Status: Public domain. The BHL considers that this work is no longer under copyright protection.

This document was created from content at the Biodiversity Heritage Library, the world's largest open access digital library for biodiversity literature and archives. Visit BHL at https://www.biodiversitylibrary.org. 